
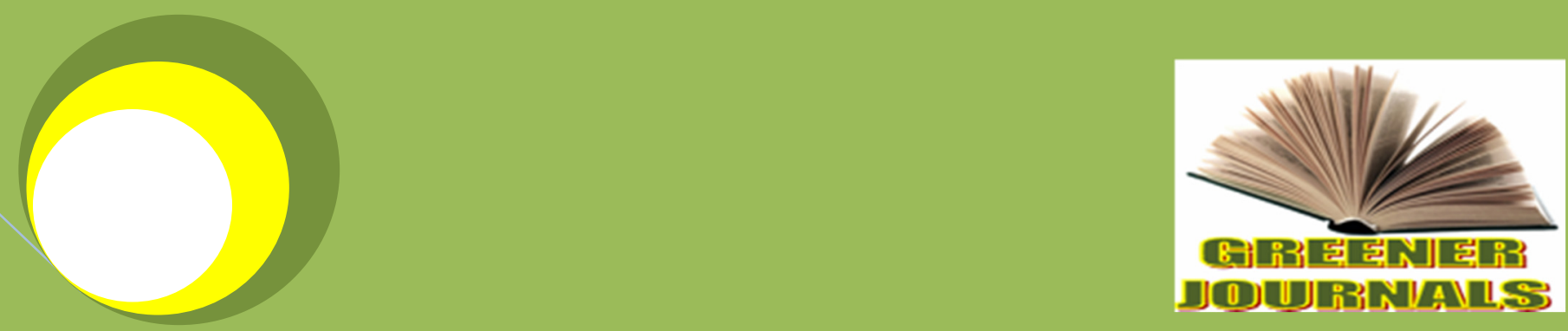

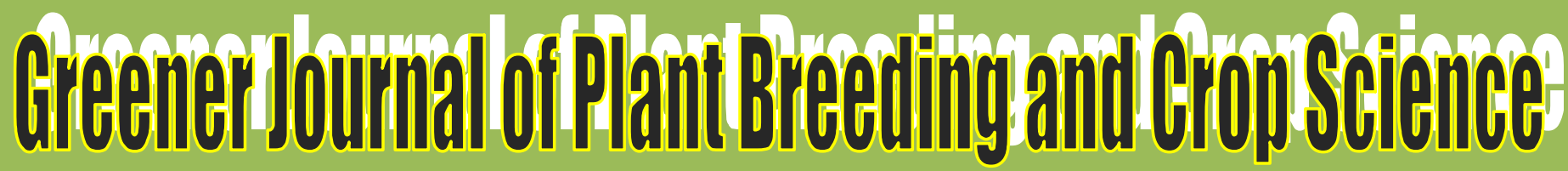

ISSN: 2354-2292

Submitted: 23/10/2015

Accepted: 30/10/2015

Published: 26/03/2016

\title{
Evaluation of Potato
}

(Solanumtuberosum L.)

Varieties for Yield and

Yield Components in

Eastern Ethiopia

By

Habtamu G

Wahassu M

Beneberu S 


\title{
Evaluation of Potato (Solanumtuberosum L.)Varieties for Yield and Yield Components in Eastern Ethiopia
}

\section{Habtamu $\mathrm{G}^{* 1}$, Wahassu $\mathrm{M}^{2}$ and Beneberu $\mathrm{S}^{3}$}

\author{
${ }^{1}$ Awada Agricultural Research Sub-Center, P.O.Box 205, Yiregalem, Ethiopia. \\ ${ }^{2}$ Haromaya University P.O.Box 138, Dire Dawa, Ethiopia. \\ *Corresponding Author’s Email: habteline @gmail .com; Mobile: +251922 490318
}

\begin{abstract}
Potato is one of the strategic crops,enhancing food security and economic benefits to Ethiopia.Ethiopia has suitable edaphic and climatic conditions for the production of potatoes. But lack of well adapted cultivars is one of a production problemsthat account for low yield and small area cropped to the nation. Therefore, this study was conducted at Haramaya, Hirna andArberekete to evaluate yield and yield component of 16 released potato varieties (Moti, Belete, Bubu, Ararsa, Gudenie, Bule, Gabissa, Marachare, Harchassa, Gera, Gorrebella, Guassa, Jalenie, Bedassa, Zemen\&Chiro) and two local cultivars (Bette \&Jarso). The experiment was laid out as a Randomized Complete Block Design with three replications. The results revealed the statistically significant variations in most of the traits. The highest total yield (56.52t/ha) and marketable tuber yield (53.97t/ha) recorded for Gera variety grown at Hirna, average tuber weight $(105.24 \mathrm{gm})$ and large sized tuber number $(56.3 \%)$ for Belete grown at Haramayalarge sized tuber weight $(80.93 \%)$ for Belete grown at Hirna, marketable tuber number $(95.83 \%)$ for Gera grown at Haramayaand unmarketable tuber weight $(55.26 \mathrm{t} / \mathrm{ha})$ were observed for Bule grown at Hirna. The high mean small size tuber number $(62.75 \%)$ for Jarso at Haramaya, small sized tuber weight $(37.42 \%)$ were observed for Marachere grown at Hirna, medium sized tuber number $(\mathbf{4 1 . 7 2 \% )}$ ) for Zemen grown at Arberekete and medium sized tuber weight $(49.13 \%)$ were observed for Bedasa variety grown at Arberekete. Finally, the result of the study reviled that the genotype and growing environment has a great influence on yield and yield components of potato tubers.
\end{abstract}

Keywords: Genotype, Growing Environment, Potato, Total tuber yield, marketable tuber Yield.

\section{INTRODUCTION}

Potato belongs to the genus Solanum that comprises about 2000 species of which only less than 10 percent is tuber bearing (Vos, 1999). The Latin name for the tetraploid potato genotypes that are grown today is SolanumtuberosumL.; with a genomic constitution of $2 n=4 x=48$. With a base $(x)$ number of twelve, the wild species occurs as diploids, triploids, tetraploids, pentaploids, and hexaploids, while the cultivated series extend to pentaploids only (Hawkes, 1978). The large genetic variation has been present among the cultivars in use. This diversity explains the widespread cultivation of potato, while individual cultivars appear best suited to specific environments (niches) (Vos, 1999).

Ethiopia has suitable edaphic and climatic conditions for the production of high quality ware and seed potatoes. Ethiopia has the potential to grow potato in $70 \%$ of the 10 million ha of arable land of the country (FAO, 2008). However, the total area under potato production is estimated 48,113 ha with total annual production of 384,046 metric tons (FAOstat, 2009).

Potato is grown in four major areas in Ethiopia: the central, the eastern, the north- western and the southern regions. Together, these areas cover approximately $83 \%$ of the potato farmers (CSA, 2008/2009). The eastern part mainly covers the eastern highlands of Ethiopia, especially the east Hararghe zone. Compared to the other parts of the country potato production, this area is characterized by higher orientation to export market particularly to Djibouti and Somalia (Adaneet al., 2010).

None of the variety or cultivar, that haswith many potential which suits in all environments and for all uses (Bradshaw et al., 2007). Therefore, assessment of genotype $\times$ environment (including end use) interactions answers the adaptation to environment and end uses.Allard (1960) described the biological complexity underlying genotype and environment. Virtually all phenotype effects are not related to gene in any simple way. Rather they result from a chain of physiochemical reactions and interactions initiated by genes but leading through complex chains of events controlled or modified by other genes and the external environment. According to Hill (1975), in Bradshaw et al., 
(2007), he stated that the accurate estimates of genetic variance for a trait of interest will be obtained if such estimates are unbiased by variation due to genotype $x$ environment interactions. It is known that the selection in one type of environment has consequences for performances in different types of environment, and Falconer and Mackay (1996) explained how these can be quantified. The improvement of performance in one environment as a result of selection in a different environment can be viewed as a correlated response and compared with the expected response from direct selection in the target environment (Bradshaw et al., 2007).

The potato's vegetative means of reproduction does lend itself to selection experiments in contrasting environments, but extensive studies have not been done (Bradshaw et al., 2007). In practice, the logistics of seed tuber multiplication mean that potato breeders are likely to select their early generations at local seed and ware sites and then test relatively few potential cultivars in a much wider range of environments. Potato producing countries should therefore have their own breeding programmes targeted at adaptation to their local environments and end uses, not withstanding commercial companies wanting to see their new cultivars grown as widely as possible (Bradshaw et al., 2007).

In Ethiopia, a number of improved potato varieties have been released by different research centres and institutions. However, there are still many farmers who grow not well adapted, poor in disease and insect pest resistant varieties. Therefore, this study was conducted with the following objective:

To evaluate yield and yield components of released potato varieties.

\section{MATERIAL AND METHODS}

\section{Description of the study area}

The field experiment was conducted under rainfed conditions during the year 2012 main cropping season at Haramaya, Hirna and Arberekete in Eastern Ethiopia.

Haramaya research site is located at $9^{\circ} 26^{\prime} \mathrm{N}$ latitude; $42^{\circ} 3^{\prime} \mathrm{E}$ longitude and at an altitude of $1980 \mathrm{~m}$.a.s.l. The mean annual rainfall is $760 \mathrm{~mm}$ (Belay et al., 1998). The mean maximum temperature is $23.4^{0} \mathrm{C}$; while, the mean minimum annual temperature is $8.25^{\circ} \mathrm{C}$. The soil of the experimental site is a well-drained deep alluvial with a subsoil stratified with loam and sandy loam (Tamire, 1973). Analysis of the chemical and physical properties of the soil indicated that it has organic carbon content of $1.15 \%$, total nitrogen content of $0.11 \%$, available phosphorus content of $18.2 \mathrm{mg} \mathrm{kg} \mathrm{soil}{ }^{-1}$, exchangeable potassium content of $0.65 \mathrm{cmolc} \mathrm{kg} \mathrm{soil}^{-1}\left(255 \mathrm{mg} \mathrm{K} \mathrm{kg} \mathrm{soil}^{-1}\right), \mathrm{pH}$ of 8.0 , and percent sand, silt and clay contents of 63,20, and 17, respectively (Simret, 2010).

The second experimental site was Hirnasub station; which is located at $9^{\circ} 12^{\prime} \mathrm{N}$ latitude, $41^{\circ} 4^{\prime} \mathrm{E}$ longitude and at an altitude of 1870 m.a.s.l. The area receives mean annual rainfall ranging from 990 to $1010 \mathrm{~mm}$. The average temperature of the area is $24.0^{\circ} \mathrm{C}$. The soil of Hirna is vertisol (Haramaya University Research Center, 1996).

The third field experimental site was Arberekete at farmer's filed, which is located at $9{ }^{\circ} 14^{\prime} \mathrm{N}$ latitude, $41^{\circ} 2^{\prime} \mathrm{E}$ longitude, and at an altitude of 2280 m.a.s.I. (ChirroZuryaworeda Agricultural Development Office, 2011).

\section{Experimental treatment and design}

A total of 16 potato genotypes which were released by different Research Centresand Haramaya University for different agro-ecologies of the country and 2 local cultivars were used for this experiment (Table 1). The experiment was laid out in a Randomized Complete Block Design (RCBD) in factorial arrangement; location and varieties as factors; where each variety was replicated three times at each location. Each plot was $3.60 \mathrm{~m} \times 4.50 \mathrm{~m}=16.2 \mathrm{~m}^{2}$ wide consisting of six rows, which accommodated 12 plants per row and thus 72 plants per plot. The spacing between plots and adjacent replication were $1 \mathrm{~m}$ and $1.5 \mathrm{~m}$, respectively. 
Table 1: Description of potato genotypes

\begin{tabular}{clccc}
\hline No & Variety & Released year & Breeder/Maintainer & $\begin{array}{c}\text { Recommended } \\
\text { Altitude (m.a.s.l.) }\end{array}$ \\
\hline 1 & Moti & 2011 & Sinnana research centre & $2400-3350$ \\
2 & Belete & 2010 & Holeta research centre & $1600-2800$ \\
3 & Bubu & 2010 & HaramayaUinversity & $1700-2000$ \\
4 & Ararsa & 2006 & Sinnana research centre & $2400-3350$ \\
5 & Gudenie & 2006 & Holeta research centre & $1600-2800$ \\
6 & Bule & 2005 & Awassa research centre & $1700-2700$ \\
7 & Gabisa & 2005 & HaramayaUinversity & $1700-2000$ \\
8 & Marachere & 2005 & Awassa research centre & $1700-2700$ \\
9 & Harchasa & 2004 & HaramayaUinversity & $1700-2000$ \\
10 & Gera & 2003 & Sheno research centre & $2700-3200$ \\
11 & Gorrebella & 2002 & Sheno research centre & $2700-3200$ \\
12 & Guassa & 2002 & Adet research centre & $2000-2800$ \\
13 & Jalenie & 2002 & Holeta research centre & $1600-2800$ \\
14 & Bedasa & 2001 & HaramayaUinversity & $1700-2400$ \\
15 & Zemen & 2001 & HaramayaUinversity & $1700-2400$ \\
16 & Chiro & 1998 & HaramayaUinversity & $1700-2400$ \\
17 & Bette & - & Local cultivar & - \\
18 & Jarso & - & Local cultivar & - \\
\hline
\end{tabular}

\section{Experimental procedures}

Land preparation: The experimental fields were cultivated by a tractor toadepthof $25-30 \mathrm{~cm}$ and levelled;thenridges weremadeby hand.

Planting: Medium sized (39-75g) Lung'ahoet al., (2007) and well sprouted tubers were planted at the sides of ridges at the spacing of $75 \mathrm{~cm}$ between ridges and $30 \mathrm{~cm}$ between tubers in July 2012 during the main growing season after the rain commenced and when the soil was moist enough to support emergence. The planting depth was maintained at $5 \mathrm{~cm}$ (Mahmoodet al., 2001).

Fertilizer application: Fertilizer was applied as the recommendation made by Haramaya University, which Phosphorus fertilizer was applied at the rate of $92 \mathrm{~kg} \mathrm{P}_{2} \mathrm{O}_{5}$ ha $^{-1}$ in the form of Diammonium Phosphate $\left(200 \mathrm{~kg} \mathrm{ha}^{-1}\right)$ and the whole rate was applied at planting. Nitrogen fertilizer was applied at the rate of $75 \mathrm{~kg} \mathrm{Nitrogen} \mathrm{ha}^{-1}$ in the form of Urea in two splits, half rate after full emergence (two weeks after planting) and half rate at the initiation of tubers (start of flowering).

Crop protection: Potato plants were treated with Mancozeb 80\% WP at the rate of $1.5 \mathrm{~kg} \mathrm{ha}^{-1}$ diluted at the rate of $40 \mathrm{~g}$ per 20 litre water once a week to control late blight disease.All other cultural practices were applied according to the regional (Haramaya University) recommendation (Teriessa, 1997).

Harvesting: The haulm were mowed two weeks before harvesting to thicken tuber periderm; as the plants reached physiological maturity, yellowing or senescence observed apparent on the lower leaves, which helped to avoid bruising and skinning during the harvesting and post-harvest handling. For the yield estimation, tubers were harvested from forty plants from the four middle rows, leaving the plants growing in the two border rows as well as those growing at both ends of each row to avoid edge effects.

\section{Data collection}

Total tuber yield ( $t / \mathrm{ha}$ ): At harvest the total tuber yield of 40 plants per plot were recorded by adding up the weights of marketable and unmarketable tubers and converted to yield per hectare.

Marketable tuber yield (t/ha): All the marketable tubers which were free from diseases, insect pests and greater than or equal to $20 \mathrm{~g}$ in weight were recorded.

Unmarketable tuber yield (t/ha): The tubers that were diseased, insect attacked and small- sized $(<20 \mathrm{~g})$ were 
recorded as unmarketable tuber yield.

Average tuber weight (g/tuber): The average tuber weight was determined by dividing the total fresh tuber yield into the respective total tubers number.

Tuber size distribution in number (\%): Tubers wererecorded by counting the number of large ( $>75 \mathrm{~g})$; medium (39$75 \mathrm{~g})$ and small $(<39 \mathrm{~g})$ at harvest and converted to percentage, according to Lung'ahoet al., (2007).

Tuber size distribution in weight (\%): Yield sample was graded into three groups, considering the weight of tubers. The grading was recorded by weighing the number of the total tubers that were categorized as large (>75g); medium $(39-75 \mathrm{~g})$ and small $(<39 \mathrm{~g})$ according to Lung'ahoet al., (2007) and the proportion of these groups of tubers were calculated in percentage.

\section{Data analysis}

The data were subjected to analysis of variance (ANOVA) using the General Linear Model (GLM) of the Statistical Analysis System (SAS) of statistical package.

\section{RESULT AND DISCUSSION}

\section{Total tuber yield}

The varieties exhibited differential yielding ability at three locations. Gera (56.52t/ha) grown at Hirna, Belete (48.29t/ha) grown at Haramayaand Belete (43.5t/ha) grown at Arberekete produced significantly highest total tuber yield per hectare. Jarso grown at Haramaya (17.70t/ha), Hirna (18.34t/ha) and Arberkete (27.55t/ha), and Bedassa (26.71t/ha) and Bette (32.7t/ha) both grown at Arberekete produced statistically significant lowest total tuber yield (Table 2). The variation in total yield of potato genotypes at different location may be due to a response of the genotypes to growing environmental factors. This suggestion is in agreement with other authors who reported that yield differences among genotypes were attributed both by the inherent yield potential of genotypes and growing environment as well as the interaction of genotype $x$ environment (Elfinesh, 2008\&Asmamawu, 2007). Singh and Singh (1973) also indicated that yield per unit area is the end product of components of several yield contributing characters which are highly influenced by the environment.

\section{Marketable tuber yield}

According to this study result, marketable tuber yield was influenced by the genotype, growing environment and the interaction effect of the genotype and growing environment. Gera (53.97t/ha) and Jarso (12.89t/ha) produced the highest and the lowest marketable tuber yield both grown at Hirna. Belete (44.71t/ha) and Jarso (16.30 t/ha) produced the highest and the lowest marketable tuber yield grown at Haramaya.Belete (42.80 t/ha) and Jarso (25.14t/ha) produced the highest and the lowest marketable tuber yield respectively, both grown at Arberkete (Table 2). Similarly, other researchers also investigated that marketable yield was significantly varied by variety, location an d genotypes x environment interaction (Elfinesh, 2008, Pandeyet al. 2004, Kumar et al., 2007).

\section{Unmarketable tuber yield}

The result of this study indicates that the the interaction of the growing environmentand genotype were significantly $(P<0.01)$ influenced as unmarketable tuber yield. Bule $(5.90 t / h a)$ grown at Hirna, Jalenie $(5.15 t / h a)$ grown at Haramaya, Marachere (4.76t/ha), Chiro (4.32 t/ha) \& Gera (4.17t/ha), all grown at Arbereketeproduced significantly highest unmarketable tuber yield. Zemen (0.3t/ha) and Gera (0.66t/ha), both grown at Haramaya, Bubu (0.5 t/ha) andArarsa (0.9t/ha) grown at Arbereketeand Hirna, respectively, produced significantly lowest unmarketable tuber yield (Table 2). The variation in non-marketable yield of the genotypes may be due to adaptability, crop maturity, and inherent ability of potato genotypes in producing unmarketable tubers per plant. The result for non-marketable yield of potato varieties in the present work is in line with the findings of Elfinesh (2008), who reported that the interaction effects of growing environment and genotype; significantly influence unmarketable tuber yield. 
Table 2: The interaction effect of location and potato genotype on total, marketable and unmarketable tuber yields (t/ha)

\begin{tabular}{|c|c|c|c|c|c|c|c|c|c|}
\hline \multirow[b]{2}{*}{ Variety } & \multicolumn{3}{|c|}{ Total tuber yield (t/ha) } & \multicolumn{3}{|c|}{ Marketable tuber yield (t/ha) } & \multicolumn{3}{|c|}{ Unmarketable tuber yield (t/ha) } \\
\hline & Haramaya & Arberkete & Hirna & Haramaya & Arberkete & Hirna & Haramaya & Arberkete & Hirna \\
\hline Moti & $26.34^{\text {hij }}$ & $31.17^{\mathrm{hg}}$ & $42.76^{d}$ & $25.48^{\text {ef }}$ & $30.00^{\mathrm{gh}}$ & $41.77^{\text {def }}$ & $0.86^{\mathrm{de}}$ & $1.17^{\text {def }}$ & $0.99^{f g}$ \\
\hline Belete & $48.29^{a}$ & $43.50^{a}$ & $54.05^{b}$ & $44.71^{a}$ & $42.80^{\mathrm{a}}$ & $52.57^{\mathrm{ab}}$ & $3.58^{\mathrm{abc}}$ & $0.70^{\text {ef }}$ & $1.48^{\text {efg }}$ \\
\hline Bubu & $36.80^{\text {cde }}$ & $38.32^{b}$ & $46.36^{c}$ & $35.62^{c}$ & $37.82^{b}$ & $45.43^{b c d}$ & $1.18^{\mathrm{cde}}$ & $0.50^{f}$ & $0.93^{\mathrm{fg}}$ \\
\hline Ararsa & $25.22^{j}$ & $33.66^{\text {ef }}$ & $39.39^{f}$ & $24.24^{f g}$ & $31.22^{\text {efg }}$ & $38.49^{\text {def }}$ & $0.98^{\mathrm{de}}$ & $2.44^{\mathrm{cd}}$ & $0.90^{\mathrm{g}}$ \\
\hline Gudenie & $34.44^{\text {ef }}$ & $36.66^{\mathrm{cb}}$ & $38.81^{f}$ & $32.95^{d}$ & $34.66^{c}$ & $37.60^{\text {def }}$ & $1.49^{\text {bcde }}$ & $2.00^{\mathrm{cd}}$ & $1.21^{\text {efg }}$ \\
\hline Bule & $29.36^{g h}$ & $29.86^{\mathrm{h}}$ & $24.15^{h}$ & $27.11^{\mathrm{e}}$ & $27.93^{\mathrm{i}}$ & $18.25^{\mathrm{g}}$ & $2.25^{\text {bcde }}$ & $1.93^{\text {cdef }}$ & $5.90^{\mathrm{a}}$ \\
\hline Gabisa & $41.57^{b}$ & $33.77^{\text {ef }}$ & $46.25^{c}$ & $39.26^{b}$ & $31.56^{\text {defg }}$ & $43.69^{\text {cde }}$ & $2.31^{\text {bcde }}$ & $2.21^{c d}$ & $2.56^{\text {cdef }}$ \\
\hline Marachere & $45.81^{a}$ & $34.98^{\mathrm{ed}}$ & $54.98^{a b}$ & $43.11^{a}$ & $30.22^{\mathrm{fgh}}$ & $50.21^{a b c}$ & $2.70^{\text {bcde }}$ & $4.76^{a}$ & $4.77^{\mathrm{cde}}$ \\
\hline Harchasa & $36.59^{\text {de }}$ & $34.84^{\mathrm{ed}}$ & $42.66^{d}$ & $32.71^{d}$ & $32.01^{\text {defg }}$ & $39.9^{\text {def }}$ & $3.88^{\mathrm{ab}}$ & $2.83^{b c}$ & $2.76^{a b}$ \\
\hline Gera & $39.41^{\mathrm{cd}}$ & $36.76^{\mathrm{cb}}$ & $56.52^{a}$ & $38.75^{b}$ & $32.59^{d c e}$ & $53.97^{\mathrm{a}}$ & $0.66^{\mathrm{e}}$ & $4.17^{\mathrm{a}}$ & $2.55^{\text {cdef }}$ \\
\hline Gorrebella & $34.52^{e f}$ & $36.41^{\mathrm{cd}}$ & $36.47^{g}$ & $33.22^{d}$ & $34.55^{c}$ & $33.69^{f}$ & $1.30^{\text {cde }}$ & $1.86^{\text {cdef }}$ & $2.78^{\mathrm{cde}}$ \\
\hline Guassa & $25.89^{\mathrm{ij}}$ & $33.83^{\text {ef }}$ & $41.73^{\text {de }}$ & $23.12^{g h}$ & $32.27^{\text {det }}$ & $37.84^{\text {det }}$ & $2.76^{\text {bcde }}$ & $1.56^{\mathrm{cdet}}$ & $3.89^{\mathrm{bcd}}$ \\
\hline Jalenie & $31.84^{\mathrm{fg}}$ & $32.82^{f g}$ & $40.43^{\text {ef }}$ & $26.69^{\mathrm{e}}$ & $31.08^{\text {efg }}$ & $35.59^{\text {ef }}$ & $5.15^{\mathrm{a}}$ & $1.74^{\text {cdef }}$ & $4.84^{a b}$ \\
\hline Bedasa & $39.84^{b c}$ & $26.71^{i}$ & $43.51^{d}$ & $37.92^{\mathrm{b}}$ & $24.34^{j}$ & $39.46^{\text {det }}$ & $1.92^{\text {bcde }}$ & $2.37^{\mathrm{cd}}$ & $4.04^{\mathrm{bc}}$ \\
\hline Zemen & $34.63^{\mathrm{ef}}$ & $34.85^{\mathrm{ed}}$ & $42.53^{\text {de }}$ & $34.33^{\mathrm{cd}}$ & $33.44^{\mathrm{dc}}$ & $40.61^{\text {def }}$ & $0.30^{\mathrm{e}}$ & $1.41^{\text {cdef }}$ & $1.92^{\text {efg }}$ \\
\hline Chiro & $28.86^{\mathrm{ghi}}$ & $37.71^{\mathrm{cb}}$ & $47.33^{c}$ & $26.96^{\mathrm{e}}$ & $33.38^{\mathrm{dc}}$ & $44.96^{\mathrm{bcd}}$ & $1.90^{\text {bcde }}$ & $4.32^{\mathrm{a}}$ & $2.37^{\text {efgd }}$ \\
\hline Bette & $25.66^{j}$ & $32.70^{i}$ & $23.16^{h}$ & $22.40^{h}$ & $28.85^{\mathrm{hi}}$ & $19.33^{g}$ & $3.26^{\mathrm{abcd}}$ & $3.86^{\mathrm{ab}}$ & $3.83^{\mathrm{bcd}}$ \\
\hline Jarso & $18.34^{k}$ & $27.55^{i}$ & $17.70^{i}$ & $16.30^{i}$ & $25.14^{j}$ & $12.89^{g}$ & $2.04^{\text {bcde }}$ & $2.41^{c d}$ & $4.81^{a b}$ \\
\hline Significance & $\star \star *$ & ** & $\star *$ & $\star *$ & $\star *$ & ** & ** & $\star *$ & ** \\
\hline CV (\%) & 5.28 & 2.82 & 2.93 & 4.06 & 6.04 & 15.01 & 19.91 & 17.22 & 19.37 \\
\hline
\end{tabular}


Marketable tuber number in percent: Significantly higher marketable tuber number in percentage was produced byGera $(95.83 \%)$, followed by Zemen $(94.25 \%)$ at Haramaya, Belete $(92.42 \%)$ followed by Bubu $(92.36 \%)$ at Arberekete and Ararsa (86.02\%) at Hirna (Table 3). Bule (44.74\%) followed by Jarso $(57.72 \%)$ both grown at Hirna, Bette (67.21\%) and Jarso (66.13\%) both grown at Haramaya produced significantly lowest marketable tuber number in percentage. The difference in tuber number might be due to varietal character and growing environmental factors.

Unmarketable tuber number in percent: Tubers of Bule $(55.26 \%)$ grown at Hirna, Jarso (33.87\%), Bette (32.29\%) both grown at Haramaya and Marachere $(30.26 \%)$ and Jarso $(29.26 \%)$ both grown at Arberekete produced significantly highest unmarketable tuber number in percentage. Gera (4.17\%) followed by Zemen (4.17\%) both grown at Haramaya recorded significantly lowest unmarketable tuber number in percentage (Table 3).

The number of tubers is the main trait that is taken into account as one of the most important traits and the yield components in the potato. The trait by the side of a tuber weight consists of two crucial components of yield component and none of the other traits have been effective as much as this in yield. The number of tubers per plot will depend mainly on the number of stems per plot, total number of stolons and stolons which tuberize. Both genetic and environmental factors play a vital role in stolon development and tuberization process (Subarta \& Upadhya, 1997).

\section{Tuber size distribution by weight and number in percentage}

Large size tuber number: The genotypes significantly differ in their ability to produce large size tuber number at all locations. Significantly highest number of large size tubers in percentage were calculated for Belete(57.76\%) grown at Haramaya and Arberekete(45.38\%);Ararsa (56.3\%) and Gudenie (36.26\%) both grown at Hirna. On the other hand, Bette (10.82\%) grown at Haramaya, Jalenie grown at Hirna (19.74\%) and Arberekete $(19.09 \%)$ as well as Bedesa (20.39\%) grown at Hirna produced significantly lowest number of large size tubers in percentage (Table 4).

Large size tuber weight: Significantly, highest large sized tubers in weight expressed in percentage were calculated for Belete grown at Haramaya (80.64\%) and Arberekete (70.97\%) and Ararsa (84.17\%) grown at Hirna. Significantly lowest percent of large sized tubers in weight were recorded for Jarso $(24.56 \%)$ and Bette $(27.44 \%)$ both grown at Haramaya, Bedessa (24.9\%) and Jarso (27.71\%) grown at Arbereketeand Hirna, respectively (Table 5).

Medium size tuber number: Significantly highest medium sized tubers number in percentage was calculated for Gudenie (40.51\%) grown at Hirna, Zemen (41.72\%) grown at Arberkete and Gera $(39.62 \%)$ grown at Haramaya. Moti at Hirna (19.61\%), Bubu at Haramaya (22.17\%) and Beddasa at Arberekete(27.74\%) produced significantly lowest number of medium sized tubers in percentage (Table 4).

Medium size tuber weight: Significant variation of medium size tubers in weight was observed among genotypes at all locations. Significantly, highest weights of medium sized tubers weight in percentage were calculated for Bedesa $(49.13 \%)$, Belete $(48.74 \%)$ and Jalenie $(39.33 \%)$ grown at Alberekete, Haramaya and Hirna, respectively. Belete at Haramaya (14.94\%) and at Arberekete(22.4\%) and Ararsa at Arberekete(23.41\%) and at Hirna (12.39\%) produced significantly lowest weight of medium sized weight tubers in percentage (Table 5).

Small size tuber number: The main effect and the interaction effect were significantly $(P<0.01)$ affected the smallsize tuber number in percentage (Appendix Table 1). Significantly, highest number of small-sized tubers in percent was calculated for Jarso grown at Haramaya (62.75\%) and at Hirna (61.32\%), Marachere (60.77\%) and Bule (61.25\%) grown at Arbereketeand Hirna, respectively. Gera at Haramaya (13.13\%) and Arberekete(22.16\%), Bubu $(19.68 \%)$ and Belete (22.04\%) both grown at Alberekete, Ararsa (18.39) at Hirna exhibited significantly lowest number of small-sized tubers in percentage (Table 4). 
Table 3: The interaction effect of location and genotype on marketable, unmarketable tuber number in percentand Average tuber weight

\begin{tabular}{|c|c|c|c|c|c|c|c|c|c|}
\hline \multirow[b]{2}{*}{ Variety } & \multicolumn{3}{|c|}{ Marketable tuber number (\%) } & \multicolumn{3}{|c|}{ Unmarketable tuber number (\%) } & \multicolumn{3}{|c|}{ Average tuber weight(gm) } \\
\hline & Haramaya & Arberkete & Hirna & Haramaya & Arberkete & Hirna & Haramaya & Arberkete & Hirna \\
\hline Moti & $82.96^{\mathrm{cd}}$ & $84.46^{b c}$ & $76.67^{\mathrm{cd}}$ & $17.04^{\mathrm{gh}}$ & $15.54^{g h}$ & $23.33^{g h}$ & $85.49^{b}$ & $64.13^{\mathrm{cd}}$ & $77.16^{d}$ \\
\hline Belete & $74.22^{\mathrm{ghi}}$ & $92.42^{\mathrm{a}}$ & $76.67^{\mathrm{cd}}$ & $25.78^{\mathrm{bcd}}$ & $7.58^{i}$ & $23.33^{g h}$ & $105.24^{\mathrm{a}}$ & $90.61^{a}$ & $103.70^{a}$ \\
\hline Bubu & $80.21^{\mathrm{cde}}$ & $92.36^{\mathrm{a}}$ & $77.25^{\mathrm{c}}$ & $19.79^{\operatorname{tgn}}$ & $7.64^{1}$ & $22.75^{\mathrm{n}}$ & $70.21^{d}$ & $71.89^{\mathrm{b}}$ & $85.02^{c}$ \\
\hline Ararsa & $87.72^{b}$ & $78.39^{\text {efgh }}$ & $86.02^{a}$ & $12.28^{i}$ & $21.61^{\text {bcde }}$ & $13.98^{j}$ & $72.15^{\mathrm{cd}}$ & $63.84^{\mathrm{cd}}$ & $95.06^{b}$ \\
\hline Gudenie & $82.05^{\mathrm{cd}}$ & $81.59^{\text {cde }}$ & $78.30^{c}$ & $17.95^{\mathrm{gh}}$ & $18.41^{\text {efg }}$ & $21.70^{\mathrm{h}}$ & $63.20^{e}$ & $55.25^{\dagger}$ & $71.03^{\mathrm{e}}$ \\
\hline Bule & $73.93^{\mathrm{ghl}}$ & $77.51^{\operatorname{tgh}}$ & $44.74^{\rfloor}$ & $26.07^{\mathrm{bcd}}$ & $22.49^{\mathrm{bcd}}$ & $55.26^{a}$ & $49.30^{\operatorname{tg}}$ & $47.33^{\mathrm{g}}$ & $39.38^{\mathrm{k}}$ \\
\hline Gabisa & $77.93^{\text {efg }}$ & $80.75^{\text {def }}$ & $78.43^{c}$ & $22.07^{\text {def }}$ & $19.25^{\text {def }}$ & $21.57^{\mathrm{h}}$ & $60.50^{\mathrm{e}}$ & $61.28^{\mathrm{de}}$ & $67.02^{\text {efg }}$ \\
\hline Marachere & $75.68^{\text {fghi }}$ & $69.40^{i}$ & $72.08^{\mathrm{ef}}$ & $24.32^{\text {bcde }}$ & $30.60^{a}$ & $27.92^{\mathrm{ef}}$ & $50.35^{\mathrm{fg}}$ & $32.80^{h}$ & $68.00^{\mathrm{ef}}$ \\
\hline Harchasa & $73.63^{\mathrm{hi}}$ & $77.59^{\text {fgh }}$ & $71.13^{\dagger}$ & $26.37^{\mathrm{bc}}$ & $22.41^{b c d}$ & $28.87^{e}$ & $46.64^{g}$ & $60.93^{\mathrm{de}}$ & $66.70^{\mathrm{fg}}$ \\
\hline Gera & $95.83^{a}$ & $76.54^{\mathrm{gh}}$ & $84.51^{\mathrm{ab}}$ & $4.17^{\mathrm{j}}$ & $23.46^{\mathrm{bc}}$ & $15.49^{\mathrm{ij}}$ & $76.48^{c}$ & $70.90^{b}$ & $68.60^{\mathrm{ef}}$ \\
\hline Gorrebella & $83.92^{\mathrm{C}}$ & $79.85^{\text {defg }}$ & $74.52^{\mathrm{de}}$ & $16.08^{h}$ & $20.15^{\text {cdef }}$ & $25.48^{f g}$ & $57.54^{\mathrm{cd}}$ & $76.48^{\mathrm{e}}$ & $59.66^{\mathrm{h}}$ \\
\hline Guassa & $72.61^{i}$ & $82.67^{\mathrm{bcd}}$ & $71.43^{f}$ & $27.39^{b}$ & $17.33^{\mathrm{fgh}}$ & $28.57^{e}$ & $54.31^{\dagger}$ & $55.73^{f}$ & $63.43^{g}$ \\
\hline Jalenie & $79.31^{\text {def }}$ & $75.28^{\mathrm{fghi}}$ & $60.60^{h}$ & $20.69^{\text {efg }}$ & $24.72^{b}$ & $39.40^{c}$ & $48.99^{9}$ & $46.15^{\mathrm{g}}$ & $47.75^{j}$ \\
\hline Bedasa & $77.49^{\text {efgh }}$ & $79.67^{\text {defg }}$ & $70.87^{f}$ & $22.51^{\text {cdef }}$ & $20.33^{\text {cdef }}$ & $29.13^{e}$ & $51.35^{\mathrm{fg}}$ & $44.62^{g}$ & $51.94^{i}$ \\
\hline Zemen & $94.27^{a}$ & $85.04^{b}$ & $83.56^{\mathrm{ab}}$ & $5.73^{j}$ & $14.96^{\mathrm{h}}$ & $16.44^{\mathrm{ij}}$ & $64.59^{e}$ & $58.87^{e}$ & $69.00^{\mathrm{ef}}$ \\
\hline Chiro & $83.33^{c}$ & $79.15^{\text {efg }}$ & $82.85^{\mathrm{b}}$ & $16.67^{\mathrm{h}}$ & $20.85^{\text {cde }}$ & $17.15^{i}$ & $64.07^{e}$ & $64.59^{c}$ & $76.42^{d}$ \\
\hline Bette & $67.21^{\jmath}$ & $76.54^{g h}$ & $63.12^{g}$ & $32.79^{\mathrm{a}}$ & $23.46^{\mathrm{bc}}$ & $36.88^{d}$ & $38.50^{\mathrm{h}}$ & $53.60^{\dagger}$ & $37.22^{k}$ \\
\hline Jarso & $66.13^{j}$ & $70.74^{i}$ & $57.72^{i}$ & $33.87^{a}$ & $29.26^{a}$ & $42.28^{b}$ & $35.98^{h}$ & $52.57^{f}$ & $31.30^{\prime}$ \\
\hline Significance & $\star *$ & $\star *$ & ** & $* *$ & ** & ** & ** & $\star \star *$ & ** \\
\hline CV (\%) & 2.74 & 2.22 & 2.06 & 10.56 & 8.88 & 5.51 & 4.61 & 3.07 & 3.38 \\
\hline
\end{tabular}


Small size tuber weight: The two main effects of the genotype and the growing environment, as well as growing environment $x$ genotype interaction were significantly $(P<0.01)$ influenced mall sized tuber weight in percentage (Appendix Table 1). Jarso (31.32\%) and Marchere (37.42\%) grown at Haramaya and Arberekete, respectively, Bule $(35.5 \%)$ and Jarso $(35.29 \%)$ both grown at Hirna exhibited significantly highest small sized tuber weight in percentage. Gera (3.7\%) and Belete (4.43\%) both grown at Haramaya, Ararsa (3.44\%) at Hirna, Bubu (5.86\%), Belete $(6.54 \%)$ and Gera $(7.62 \%)$ all grown at Arberekete produced significantly lowest small sized tuber weight in percentage (Table 5).

The observed significant variations among the genotypes across growing environments (locations) for tuber size distribution in number and weight may be attributed to inherent potential of such genotypes which were highly influenced by growing conditions and interaction of genotype and environment. Muthuraj et al., (2005) reported that the effect of heredity was significant with regard to tuber grades. One of the essential factors that affect the percentage of different tuber sizes is vegetative growth and stem numbers that influence varieties differentially (Azad et al., 1997).

Kumar and Ezekiel (2006) and Patel et al., (2008) described that rapid plant emergence and better plant growth results in higher number of medium size tubers. Sufficient growth (stem number and plant height) had positive contribution to tuber number. Patel et al.,(2008) and Kumar et al., (2007) reported that maximum yield of small size tubers may be due to higher number of tubers as well as varietal character, adaptability or establishment effects of the other growth attributes. More number of under size tubers may be due to the higher vigor of plants coupled with delayed maturity (Sharma \& Singh, 2009). According to the farmers choice, it is not a good character of any variety to produce small tubers, because it doesn't benefit farmers' as the market value of small tubers is very low. As regards of the marketability, the variety which produced more number of large and medium size tubers is considered the best.

\subsubsection{Average tuber weight}

The main effects as well as the interaction effect were significantly $(P<0.01)$ influenced average tuber weight (Appendix Table 1). Belete grown at all locations viz. Haramaya (104.24g), Hirna (103.78g) and Arberekete (90.6g) produced significantly highest average tuber weight. Ararsa $(95.6 \mathrm{~g})$ and Moti (85.49) grown at Hirna and Haramaya respectively, as well as Bubu (71.89\%) and Gera $(70.9 \mathrm{~g})$ both grown at Arberekete produced the highest and significant average tuber weight. On the contrary, Jarso $(35.98 \mathrm{~g})$ and Bette $(38.5 \mathrm{~g})$ both grown at Haramaya, Marachere $(32.8 \mathrm{~g})$ and Jarso $(37.3 \mathrm{~g})$ both grown at Arberekete produced significantly lowest average tuber weight.

The variation may be attributed to an inherit potential of the genotypes as well as the interaction of genotype and environmental condition. Patel et al., (2008) and Kumar et al., (2007) also reported that maximum yield of small size tubers may be due to higher number of tubers as well as varietal character and adaptability or establishment effect of other growth attributes. Muthurajet al., (2005) reported that, the effect of heredity was significant with regard to tuber grades. One of the essential factors that affect the percentage of different tuber sizes is vegetative growth and stem numbers but the influence on different varieties is different (Azad et al., 1997). More number of under size tubers may be due to the higher vigor of plants coupled with delayed maturity (Sharma \& Singh, 2009). According to the farmer's choice, it is not a good character of variety to produce small tubers; because it is of no benefit for the farmer as the market value of small tubers is very low. The variety, whichproduced more number of large and medium tubers, is considered to be the best regarding marketability. 
Table 4: The interaction effect of location and potato genotype on large, medium and small tuber number in percentage

\begin{tabular}{|c|c|c|c|c|c|c|c|c|c|}
\hline \multirow[b]{2}{*}{ Variety } & \multicolumn{3}{|c|}{ Large tuber number (\%) } & \multicolumn{3}{|c|}{ Medium tuber number (\%) } & \multicolumn{3}{|c|}{ Small tuber number (\%) } \\
\hline & Haramaya & Arberkete & Hirna & Haramaya & Arberkete & Hirna & Haramaya & Arberkete & Hirna \\
\hline Moti & $37.09^{\dagger}$ & $31.09^{d}$ & $41.37^{d}$ & $30.33^{\mathrm{bcd}}$ & $39.23^{\mathrm{ab}}$ & $19.61^{\dagger}$ & $32.58^{\mathrm{ef}}$ & $29.68^{9}$ & $39.02^{e}$ \\
\hline Belete & $52.76^{\mathrm{a}}$ & $45.38^{\mathrm{a}}$ & $47.99^{b c}$ & $26.01^{\mathrm{de}}$ & $32.58^{\text {def }}$ & $26.84^{\mathrm{c}}$ & $21.24^{i}$ & $22.04^{\mathrm{h}}$ & $25.17^{\text {ghi }}$ \\
\hline Bubu & $44.26^{\mathrm{C}}$ & $41.33^{b}$ & $49.88^{b}$ & $22.17^{\mathrm{e}}$ & $38.99^{\mathrm{ab}}$ & $25.69^{\text {cd }}$ & $33.58^{\text {ef }}$ & $19.68^{\mathrm{h}}$ & $24.43^{\mathrm{hi}}$ \\
\hline Ararsa & $41.62^{d}$ & $27.40^{\text {ef }}$ & $56.31^{a}$ & $31.15^{\mathrm{bcd}}$ & $37.70^{\mathrm{abc}}$ & $25.29^{\text {cde }}$ & $27.23^{\text {gh }}$ & $34.90^{\text {ef }}$ & $18.39^{j}$ \\
\hline Gudenie & $29.17^{\mathrm{ij}}$ & $29.47^{\mathrm{de}}$ & $36.26^{\mathrm{e}}$ & $35.63^{\mathrm{abc}}$ & $33.02^{\text {cde }}$ & $40.51^{a}$ & $35.21^{\text {def }}$ & $37.51^{\text {de }}$ & $23.23^{i}$ \\
\hline Bule & $19.14^{\prime}$ & $22.64^{9}$ & $16.13^{\text {gh }}$ & $27.98^{\mathrm{de}}$ & $36.30^{\mathrm{bcd}}$ & $22.62^{\text {def }}$ & $52.88^{\mathrm{b}}$ & $41.06^{\mathrm{cd}}$ & $61.25^{\mathrm{a}}$ \\
\hline Gabisa & $32.31^{\text {gh }}$ & $25.21^{\mathrm{fg}}$ & $36.40 \mathrm{e}$ & $29.87^{\text {bcd }}$ & $39.60^{\mathrm{ab}}$ & $22.07^{\text {ef }}$ & $37.82^{\text {de }}$ & $35.19^{\text {ef }}$ & $41.54^{\text {cde }}$ \\
\hline Marachere & $19.72^{\prime}$ & $7.26^{i}$ & $32.59^{\text {ef }}$ & $30.93^{\mathrm{bcd}}$ & $31.97^{\text {def }}$ & $27.47^{c}$ & $49.34^{\mathrm{bc}}$ & $60.77^{\mathrm{a}}$ & $39.94^{\text {de }}$ \\
\hline Harchasa & $33.66^{g}$ & $30.56^{\mathrm{de}}$ & $36.87^{e}$ & $26.77^{\text {de }}$ & $38.58^{\mathrm{ab}}$ & $33.80^{b}$ & $39.57^{d}$ & $30.86^{g}$ & $29.33^{\text {fgh }}$ \\
\hline Gera & $47.26^{b}$ & $42.51^{\mathrm{ab}}$ & $47.83^{b c}$ & $39.62^{\mathrm{a}}$ & $35.33^{\mathrm{bcd}}$ & $22.63^{\text {def }}$ & $13.13^{j}$ & $22.16^{\mathrm{h}}$ & $29.53^{\mathrm{fgh}}$ \\
\hline Gorrebella & $39.23 \mathrm{e}$ & $28.57^{\mathrm{de}}$ & $31.80^{\dagger}$ & $29.23^{d}$ & $31.36^{\mathrm{ef}}$ & $35.36^{\mathrm{b}}$ & $31.54^{\mathrm{fg}}$ & $40.07^{d}$ & $32.84^{\dagger}$ \\
\hline Guassa & $24.81^{9}$ & $29.00^{\mathrm{de}}$ & $36.50^{\mathrm{e}}$ & $29.80^{\mathrm{bcd}}$ & $35.18^{\mathrm{bcd}}$ & $25.20^{\text {def }}$ & $45.40^{c}$ & $35.83^{\text {ef }}$ & $38.30^{\mathrm{e}}$ \\
\hline Jalenie & $16.04^{\mathrm{m}}$ & $19.09^{h}$ & $19.74^{g}$ & $35.55^{\mathrm{abc}}$ & $40.31^{\mathrm{ab}}$ & $35.66^{\mathrm{b}}$ & $48.42^{\mathrm{bc}}$ & $40.60^{c d}$ & $44.61^{c d}$ \\
\hline Bedasa & $27.87^{j}$ & $23.38^{\mathrm{g}}$ & $20.37^{9}$ & $27.45^{\mathrm{de}}$ & $27.74^{\dagger}$ & $34.11^{b}$ & $44.68^{c}$ & $48.88^{\mathrm{b}}$ & $45.53^{c}$ \\
\hline Zemen & $44.92^{\mathrm{c}}$ & $22.17^{\mathrm{g}}$ & $41.90^{d}$ & $30.75^{\mathrm{bcd}}$ & $41.72^{\mathrm{a}}$ & $27.92^{c}$ & $24.32^{\mathrm{hi}}$ & $36.10^{\text {ef }}$ & $30.17^{f g}$ \\
\hline Chiro & $30.79^{\mathrm{hi}}$ & $37.44^{c}$ & $45.02^{c d}$ & $32.04^{\mathrm{bcd}}$ & $32.70^{\text {cdef }}$ & $28.39^{c}$ & $37.17^{\mathrm{de}}$ & $29.85^{\mathrm{g}}$ & $26.59^{\text {ghi }}$ \\
\hline Bette & $10.82^{n}$ & $30.00^{\mathrm{de}}$ & $14.24^{\text {ih }}$ & $35.96^{\mathrm{ab}}$ & $36.75^{\mathrm{abcd}}$ & $34.08^{b}$ & $53.22^{b}$ & $33.24^{\mathrm{fg}}$ & $51.67^{b}$ \\
\hline Jarso & $7.79^{\circ}$ & $24.29^{9}$ & $11.00^{\prime}$ & $29.47^{d c}$ & $31.68^{\text {det }}$ & $27.68^{\mathrm{C}}$ & $62.75^{\mathrm{a}}$ & $44.03^{\mathrm{C}}$ & $61.32^{\mathrm{a}}$ \\
\hline Significance & ** & & ** & $\star \star *$ & ** & ** & $\star * *$ & $* *$ & ** \\
\hline CV (\%) & 3.62 & 6.13 & 7.20 & 10.57 & 7.46 & 6.32 & 7.67 & 6.16 & 7.79 \\
\hline
\end{tabular}


Table 5: The interaction effect of location and genotype on large, medium and small tuber size in weight

\begin{tabular}{|c|c|c|c|c|c|c|c|c|c|}
\hline \multirow[b]{2}{*}{ Variety } & \multicolumn{3}{|c|}{ Large tuber weight (\%) } & \multicolumn{3}{|c|}{ Medium tuber weight (\%) } & \multicolumn{3}{|c|}{ Small tuber weight (\%) } \\
\hline & Haramaya & Arberkete & Hirna & Haramaya & Arberkete & Hirna & Haramaya & Arberkete & Hirna \\
\hline Moti & $67.82^{\mathrm{cd}}$ & $48.60^{\text {fgh }}$ & $72.87^{\mathrm{cd}}$ & $22.19^{h}$ & $41.22^{\mathrm{bc}}$ & $15.85^{\text {fgh }}$ & $9.98^{\text {fgh }}$ & $10.19^{\mathrm{h}}$ & $11.28^{\text {cdefg }}$ \\
\hline Belete & $80.64^{a}$ & $70.97^{a}$ & $80.93^{b}$ & $14.94^{\mathrm{j}}$ & $22.49^{h}$ & $13.95^{\mathrm{gh}}$ & $4.43^{i}$ & $6.54^{i}$ & $5.12^{\mathrm{fg}}$ \\
\hline Bubu & $72.08^{b}$ & $60.33^{c}$ & $75.77^{c}$ & $19.39^{i}$ & $33.82^{\mathrm{ef}}$ & $18.61^{\text {efgh }}$ & $8.53^{g h}$ & $5.86^{i}$ & $5.62^{\mathrm{efg}}$ \\
\hline Ararsa & $66.26^{d}$ & $66.55^{\mathrm{b}}$ & $84.17^{\mathrm{a}}$ & $25.09^{9}$ & $23.46^{\mathrm{h}}$ & $12.39^{\mathrm{h}}$ & $8.65^{\mathrm{gh}}$ & $9.99^{h}$ & $3.44^{\mathrm{g}}$ \\
\hline Gudenie & $54.73^{g}$ & $54.94^{\mathrm{de}}$ & $60.74^{\dagger}$ & $34.32^{c}$ & $34.42^{\text {ef }}$ & $32.14^{\mathrm{bc}}$ & $10.96^{\text {etg }}$ & $10.64^{\mathrm{h}}$ & $7.12^{\text {detg }}$ \\
\hline Bule & $46.53^{h}$ & $39.16^{\mathrm{jk}}$ & $44.36^{i j}$ & $31.56^{d}$ & $44.05^{b}$ & $20.14^{\text {def }}$ & $21.91^{b}$ & $16.79^{\text {de }}$ & $35.50^{\mathrm{a}}$ \\
\hline Gabisa & $60.92^{\mathrm{e}}$ & $42.03^{\mathrm{ij}}$ & $67.51^{\mathrm{e}}$ & $25.98^{g}$ & $43.32^{b}$ & $20.08 e^{f g}$ & $13.10^{\text {def }}$ & $14.64^{\text {ef }}$ & $12.40^{\text {cdef }}$ \\
\hline Marachere & $46.18^{h}$ & $20.71^{m}$ & $62.61^{f}$ & $35.13^{c}$ & $41.87^{\mathrm{bc}}$ & $23.99^{\text {de }}$ & $18.69^{c}$ & $37.42^{\mathrm{a}}$ & $13.39^{\text {bcde }}$ \\
\hline Harchasa & $47.42^{h}$ & $50.70^{\mathrm{fg}}$ & $63.66^{f}$ & $35.91^{c}$ & $36.08^{\mathrm{de}}$ & $27.64^{\mathrm{cd}}$ & $16.67^{c}$ & $13.22^{\mathrm{fg}}$ & $8.71^{\text {cdefg }}$ \\
\hline Gera & $66.30^{d}$ & $61.79^{b}$ & $70.73^{\mathrm{de}}$ & $30.00^{\mathrm{de}}$ & $30.59^{\mathrm{fg}}$ & $17.04^{\text {efgh }}$ & $3.70^{i}$ & $7.62^{i}$ & $12.23^{\text {cdef }}$ \\
\hline Gorrebella & $57.51^{\mathrm{bc}}$ & $66.30^{\mathrm{cd}}$ & $58.54^{g}$ & $31.49^{h}$ & $30.00^{g}$ & $29.31^{b c}$ & $11.00^{h}$ & $3.70^{j}$ & $12.16^{\text {cdefg }}$ \\
\hline Guassa & $47.29^{h}$ & $45.13^{h i}$ & $64.11^{f}$ & $30.57^{d}$ & $39.08^{\mathrm{cd}}$ & $22.56^{\text {def }}$ & $22.14^{b}$ & $15.79^{e}$ & $13.34^{\text {bcde }}$ \\
\hline Jalenie & $33.56^{i}$ & $40.30^{\mathrm{jk}}$ & $45.50^{i}$ & $43.91^{b}$ & $43.35^{b}$ & $39.33^{a}$ & $22.53^{b}$ & $16.35^{\mathrm{de}}$ & $15.17^{\mathrm{cb}}$ \\
\hline Bedasa & $57.48^{\text {fg }}$ & $24.90^{\prime}$ & $48.74^{h}$ & $26.83^{\text {fg }}$ & $49.13^{a}$ & $37.40^{a b}$ & $15.69^{\mathrm{cd}}$ & $25.97^{b}$ & $13.87^{\mathrm{cbd}}$ \\
\hline Zemen & $61.26^{\mathrm{e}}$ & $36.86^{k}$ & $69.64^{\mathrm{de}}$ & $28.27^{\mathrm{ef}}$ & $43.58^{b}$ & $21.17^{\text {det }}$ & $10.47^{\text {etgh }}$ & $19.55^{\mathrm{C}}$ & $9.19^{\text {cdetg }}$ \\
\hline Chiro & $59.87^{\text {ef }}$ & $58.27^{\mathrm{cd}}$ & $71.51^{d}$ & $26.57^{\mathrm{fg}}$ & $30.85^{\mathrm{fg}}$ & $21.98^{\text {def }}$ & $13.56^{\mathrm{de}}$ & $10.88^{h}$ & $6.51^{\text {defg }}$ \\
\hline Bette & $27.44^{j}$ & $52.31^{\text {ef }}$ & $41.93^{j}$ & $48.74^{a}$ & $34.40^{\text {ef }}$ & $37.64^{a b}$ & $23.82^{b}$ & $13.28^{f g}$ & $20.43^{b}$ \\
\hline Jarso & $24.56^{j}$ & $47.98^{g h}$ & $27.71^{\mathrm{k}}$ & $44.13^{b}$ & $33.76^{\text {ef }}$ & $37.00^{a b}$ & $31.32^{\mathrm{a}}$ & $18.26^{\mathrm{cd}}$ & $35.29^{a}$ \\
\hline Significance & $* *$ & $* *$ & $\star \star$ & $\star *$ & $\star *$ & $\star \star$ & $\star *$ & $\star *$ & $* *$ \\
\hline CV (\%) & 3.30 & 4.46 & 3.08 & 4.06 & 6.04 & 15.01 & 12.05 & 8.33 & 18.72 \\
\hline
\end{tabular}


Table 6: The interaction effect of location and genotype on average tuber weight

\begin{tabular}{|c|c|c|c|}
\hline \multirow[b]{2}{*}{ Variety } & \multicolumn{3}{|c|}{ Average tuber weight(gm) } \\
\hline & Haramaya & Arberkete & Hirna \\
\hline Moti & $85.49^{\circ}$ & $64.13^{\mathrm{cd}}$ & $77.16^{d}$ \\
\hline Belete & $105.24^{a}$ & $90.61^{a}$ & $103.70^{\mathrm{a}}$ \\
\hline Bubu & $70.21^{d}$ & $71.89^{\mathrm{b}}$ & $85.02^{c}$ \\
\hline Ararsa & $72.15^{\mathrm{cd}}$ & $63.84^{\mathrm{cd}}$ & $95.06^{\mathrm{b}}$ \\
\hline Gudenie & $63.20^{\mathrm{e}}$ & $55.25^{\dagger}$ & $71.03^{\mathrm{e}}$ \\
\hline Bule & $49.30^{\text {tg }}$ & $47.33^{\mathrm{g}}$ & $39.38^{k}$ \\
\hline Gabisa & $60.50^{\mathrm{e}}$ & $61.28^{\mathrm{de}}$ & $67.02^{\text {etg }}$ \\
\hline Marachere & $50.35^{\text {tg }}$ & $32.80^{n}$ & $68.00^{\mathrm{et}}$ \\
\hline Harchasa & $46.64^{g}$ & $60.93^{\mathrm{de}}$ & $66.70^{\text {tg }}$ \\
\hline Gera & $76.48^{\mathrm{c}}$ & $70.90^{\mathrm{b}}$ & $68.60^{\text {et }}$ \\
\hline Gorrebella & $57.54^{\mathrm{cd}}$ & $76.48^{\mathrm{e}}$ & $59.66^{\mathrm{h}}$ \\
\hline Guassa & $54.31^{\dagger}$ & $55.73^{\dagger}$ & $63.43^{9}$ \\
\hline Jalenie & $48.99^{9}$ & $46.15^{\mathrm{g}}$ & $47.75^{\jmath}$ \\
\hline Bedasa & $51.35^{\operatorname{tg}}$ & $44.62^{9}$ & $51.94^{\prime}$ \\
\hline Zemen & $64.59^{\mathrm{e}}$ & $58.87^{\mathrm{e}}$ & $69.00^{\mathrm{et}}$ \\
\hline Chiro & $64.07^{\mathrm{e}}$ & $64.59^{c}$ & $76.42^{\mathrm{d}}$ \\
\hline Bette & $38.50^{\mathrm{n}}$ & $53.60^{\dagger}$ & $37.22^{\mathrm{k}}$ \\
\hline Jarso & $35.98^{n}$ & $52.57^{\dagger}$ & $31.30^{\prime}$ \\
\hline Significance & ** & ** & ** \\
\hline CV (\%) & 4.61 & 3.07 & 3.38 \\
\hline
\end{tabular}

Means followed by the same letter with in a column are not significantly different.

\section{SUMMARY AND RECOMMENDATION}

The results revealed that significant differences were observed in yield and yield components of Potato tuber. The analysis of the variance indicated that varieties' yield was significantly influenced by the genotype, growing environment and the interaction of genotype by environment. According to this study result, yield and yield components of the potato tubers varied from one variety to another within the same variety on different growing environmental conditions. Therefore, Haramaya, Hirna and Arberekete farmers have to choose the varieties which suit their own growing environment; that is probably the most critical decision with respect to matching tuber quality with intended market and economic benefit to them. According to this study result, Belete, Marachare and Gbisa varieties are superior in total yield and marketable yield in decreasing order at Haramaya growing environments and Gera, Belete and Marachare varieties were suitable at Hirnain decreasing order listed here; whereas Belete, Bubu, Gera and Gudenie varieties were recommended for Arberekete Growing environments.

\section{ACKNOWLEDGEMENT}

I would like to acknowledge the financial support provided by Haramaya University potato research program. I highly appreciate and acknowledge the effort made by Haramaya University field assistants for their unreserved support and substantial contribution to accomplish this study. 


\section{REFERENCE}

Adane H., Miranda P.M., Meuwissen A.T., Willemien J.M., Lommen A.O.L., Admasu T. and Paul C.S. (2010). Analysis of Seed Potato Systems in Ethiopia.Am. J. Pot Res, 87:537-552

Asmamaw Y., (2007). Postharvest quality of potato (Solanumtuberosum L.) cultivars as influenced by growing environment and storage period. An M. Sc. Thesis submitted to the school of graduate studies of Haramaya University, 41-44p.

Azad S.,Nehra B.K., Khurana S.C. and Singh N., (1997). Influence of plant density and geometry on growth and yield in seed crop of potato. Indian Potato Assoc., 24(1-2): 17-23.

Belay S.C.,Wortman W. and Hoogen B.G., (1998). Haricot bean agro-ecology in Ethiopia: definition using agroclimatic and crop growth stimulation models. African Crop Science Journal.6: 9-18.

Bradshaw J., christiane G., Francine G., Donald K., Mackerron L,, Mark A.T. and Heather A.R., (2007). Potato biology and bitechnology advances and perspectives.

CSA (Central Statistical Agency).(2009). Agricultural sample survey: Report on area and production of crops, Addis Abeba, Ethiopia, p. 126.

Elfinesh F., (2008). Processing quality of improved Potato (SolanumtuberosumL.) varieties as influenced by growing environment, genotype and blanching. An M. Sc. Thesis submitted to the school of graduate studies of Haramaya University

Falconer P. and Mackay G.R., 1996.Potato genetics.Potato Res. 39, 387.

FAO. (2008). Potato World: Africa-International Year of the Potato. (http://www.potato2008.org/en/world/africa.html).

FAOSTAT DATA, (2004).Agricultural data.Provisional 2003 Production Indices Data.Crop Primary (http://apps.fao.org/default.jsp).

FAOSTAT DATA, (2009).Agricultural data.Provisional 2009 Production Indices Data.Crop Primary. (http://apps.fao.org/default.jsp).

Hawkes J.C., (1978). The Potato: Evolution, Biodiversity, and Genetic Resources. Belhaven Press, London. 259 P.

Hawkes J.C., (1990). The potato: Evolution, Biodiversity and Genetic Resources. Belhaven Press, London. P259.

Kumar D. and Ezekiel R.,(2006). Effect of physiological and biochemical attributes of potato cultivars KufriLauvkar and Atlantic on their chipping quality. Am. Potato J., 33(1-2): 50-55.

Kumar S., Khade H.D.,Dhokane V.S., Bethere A.G., and Sharma A., (2007). Irradiation in Combination With Higher Storage Temperatures Maintains Chip-Making Quality of Potato. J.Food sci.72.

Lung'aho C.,LemagaB., Nyongesa M., Gildermacher P., Kinyale P., Demo P. and Kabira J., (2007). Commercial seed potato production in eastern and central Africa. Kenya Agricultural Institute, Kenya. 140p.

Mahmood M. M., Hussain A. and Farooq K., (2001)."Aallo Ki Kasht” 9 p. National Potato Programme, NARC. 59p.

Muthuraj R., Ravichandran G., Krishna K.S. and Singh S., (2005). Effect of planting date on seed size tuber yield of potato in Nilgiris. Potato J., 32(3-4): 239.

Pandey S.K., Sing S.V., Kumar P. and ManivelP..(2004). Sustaining potato chipping Industry from western and central Uttar Pardesh: Adoption of suitable varieties. Potato J., 31(3-4): 119-127.

Patel C.K., Patel P.T. andChaudhari S.M., (2008). Effect of physiological age and seed size on seed production of potato in North Gujarat, 35: 85-87.

Sharma A.K. and SinghS..(2009). Effect of seed tuber desprouting on potato production in kufriGriraj.Potato J., 36: 51-56.

Simret B., (2004). Influence of inorganic nitrogen and potassium fertilizers on seed tuber yield and size distribution of potato (Solanumtuberosum L.). An. M. Sc Thesis Presented to the School of Graduate Studies of Haramaya University, Ethiopia. 65p.

SinghT.P., and Singh K.B., (1973). Association of grain yield and its components in segregations of green gram. Indi. J. Genetics. 33: 112-117.

Subarta M. and Upadhya M.O., (1997).Potato production in western Bengal.Environmental. Ecology Journal.15: 646900.

Teriessa J., (1997).A Simple guide for potato production in Eastern Ethiopia. Ethiopia Alemaya University, Ethiopia.

Vos J., (1999). Potato. In: Crop yield: physiology and processes. Donald L.S.,Chantal Hamel (Eds.). Springer-Verlag, Berlin.

Cite this Article: Habtamu G, Wahassu M and Beneberu S (2016). Evaluation of Potato (Solanumtuberosum L.) Varieties for Yield and Yield Components in Eastern Ethiopia. Greener Journal of Plant Breeding and Crop Science, 4(2): 014-026, http://doi.org/10.15580/GJPBCS.2016.2.102315146 


\section{APPENDIX TABLE}

Appendix table 1 Mean squares for physical parameters of potato genotypes grown at Haramaya, Hirna and Arberkete and their interaction

\begin{tabular}{|c|c|c|c|c|c|c|c|c|c|c|c|c|c|c|}
\hline \multirow[b]{2}{*}{ S.V } & \multirow[b]{2}{*}{ d.f } & \multicolumn{2}{|c|}{ Mean square } & \multirow[b]{2}{*}{$\begin{array}{c}\text { UMT } \\
\text { W }\end{array}$} & \multirow[b]{2}{*}{ MTN } & \multirow[b]{2}{*}{ UMTN } & \multirow[b]{2}{*}{ ATW } & \multirow[b]{2}{*}{ LTS } & \multirow[b]{2}{*}{ MTS } & \multirow[b]{2}{*}{ STS } & \multirow[b]{2}{*}{ LTW } & \multirow[b]{2}{*}{ MTW } & \multirow[b]{2}{*}{ STW } & \multirow[b]{2}{*}{ PC } \\
\hline & & TTY & MTY & & & & & & & & & & & \\
\hline Reps & 2 & $3.064^{\mathrm{ns}}$ & $10.650^{\text {ns }}$ & 1.325 & $3.746^{\mathrm{ns}}$ & $3.746^{\mathrm{ns}}$ & $18.590^{\mathrm{ns}}$ & $1.84^{\mathrm{ns}}$ & $12.375^{\mathrm{ns}}$ & $4.859^{\mathrm{ns}}$ & $4.162^{\mathrm{ns}}$ & $10.65^{\mathrm{ns}}$ & $5.98^{\mathrm{ns}}$ & $1.484 \mathrm{~ns}$ \\
\hline Var & 17 & $396.841^{* *}$ & $403.885^{\star \star}$ & $8.849^{* *}$ & $403.766^{* *}$ & ${ }_{*}^{4} 03.766^{*}$ & $2032_{\star} .135^{\star}$ & $993.030^{*}$ & $62.068^{* *}$ & $944.204^{*}$ & $1402.129^{* *}$ & $403.885^{* *}$ & $396.140 *$ & $16.57^{\star *}$ \\
\hline Loc & 2 & $934.615^{* *}$ & ${ }_{*} 1742.457^{\star}$ & $8.775^{* *}$ & $855.709^{* \star}$ & $855.709^{*}$ & $615.731^{* \star}$ & $468.788^{\star}$ & $700.423^{* *}$ & $95.103^{\star *}$ & $2203.880^{* *}$ & $1742.46^{* *}$ & $34.102^{* *}$ & $84.95^{\star *}$ \\
\hline $\begin{array}{l}\text { Var* Lo } \\
\text { C }\end{array}$ & 34 & $84.343^{* *}$ & $113.993^{* *}$ & $3.812^{* *}$ & $118.296^{* *}$ & 118.296 & $221.573^{* *}$ & 144.311 & $65.564^{* *}$ & $150.77^{* *}$ & $266.049^{\star *}$ & $113.993^{* *}$ & $94.525^{\star *}$ & $5.867^{\star *}$ \\
\hline Error & 106 & 1.79 & 6.74 & 0.97 & 3.55 & 3.55 & 5.63 & 3.53 & 6.73 & 7.16 & 3.79 & 6.74 & 6.98 & 2.239 \\
\hline
\end{tabular}

** Significant at $\mathrm{P}<0.01$, * Significant at $\mathrm{P}<0.05$, ns non significant at $\mathrm{P}<0.05$ probability level.

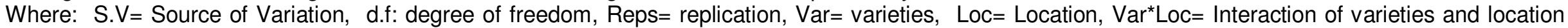

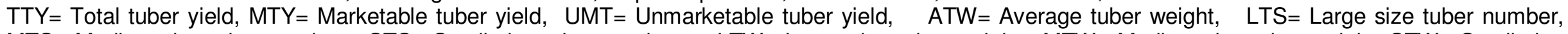

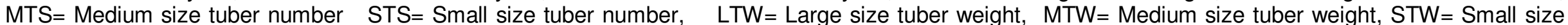
tuber weight and $\mathrm{PC}=$ peel content. 